\title{
An irresistible beauty in 1 Peter
}

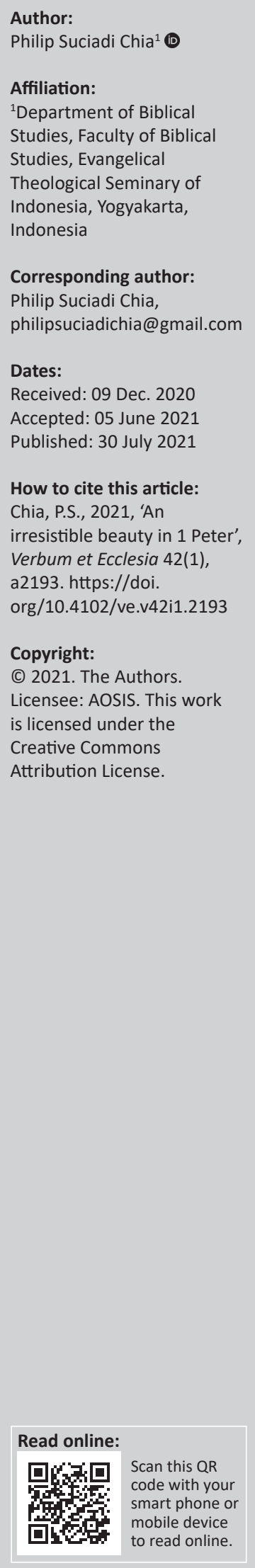

1 Peter 3:1-5 is a paraenesis to wives concerning their identity, as Christ's followers, to offer up glory to God with their status as wives. In Graeco-Roman marriage, being Christians held the potential for serious problems because of their belief and relationship with the society. In the midst of these challenges, Peter does not admonish wives to reject their Christian faith nor to merge their husbands' religion(s) with Christianity. Instead, Peter calls them to remain committed completely to their faith and to their husbands (1 $\mathrm{Pt} 3: 1)$. Therefore, this article attempts to demonstrate the accuracy of the above interpretation of 1 Peter 3:1-5. My thesis is as follows: Peter encourages a unique way to live as wives, that is, seeking an irresistible beauty, which is inward life, as a living testimony to your husband.

Intradisciplinary and/or interdisciplinary implications: This study contributes to gender studies through an exegetical study in 1 Peter.

Keywords: gender; Greek New Testament; 1 Peter; submission; living testimony.

\section{Introduction}

In Jewish culture, a woman was the mistress of the home but was not qualified to appear as a witness in the court and was exempt from fulfilling her religious duties. In Roman culture, it is ideal for women to pass from the subjection of their father to their husband (Ferguson 2003:78). In Graeco-Roman society, it was expected that the wife would not have her own friends and would worship the gods of her husband. If this expectation was applied to a Christian wife, it might result in trouble for several reasons. Firstly, the very fact that a woman would adopt any religion other than her husband's violated the Graeco-Roman ideal of an orderly home. Even more germane to this text is that a wife was expected to worship her husband's god(s) or face the charge of atheism. Therefore, in early Christianity, we find examples where the man's conversion to Christianity implies the conversion of the entire household (Jn 4:53; Ac 16:31-34, 18:18; 1 Cor 1:16; Heb 11:7). Christians were frequently blamed for public calamity because they introduced a new god, upsetting the religious status quo of the empire (Frend 1967:137; Oborn 1939:131-148). Secondly, the husband and society would perceive the wife's worship of Jesus Christ as rebellion, especially if she worshipped Christ exclusively, resulting in embarrassment and criticism amongst husbands for not properly managing their household. This could seriously damage his social standing, even to the point of disqualifying him for certain honours and offices (Jobes 2005:203). Thirdly, those wives who reject the family religion determined by their husbands would be particularly threatening to fathers, because wives were responsible for raising children for the first period of their lives (Davids 2005:226).

In the midst of these challenges, Peter does not admonish wives to reject their Christian faith, nor to merge their husbands' religion(s) with Christianity (Dinkler 2007:10). Instead, Peter calls them to remain committed completely to their faith and committed completely to their husbands (1 Pt 3:1). 1 Peter 3:2 says that whilst all believers are to respond to unbelievers with a verbal account of their hope, the response of wives towards their unbelieving husbands is to be marked by pure and reverent or chaste conduct alone (Brown 2004:395-403). He also exhorts the wives to have an irresistible beauty by defining it as inward life and explains it in negative (1 $\mathrm{Pt} \mathrm{3:3)}$ and positive ways (1 Pt 3:4). At the end, he closes his exhortation to wives with the reasons for their submission by presenting the example of holy women in the past, in particular, the example of Sarah (1 Pt 3:5-6).

In this study, The author attempts to demonstrate the accuracy of the above interpretation of 1 Peter 3:1-5. My thesis is as follows: Peter encourages a unique way to live as wives: seeking an irresistible beauty, which is inward life, as a living testimony to your husband. 


\section{Peter 3:1-2: Submission as living testimony}

3:1: ónoí $\omega \varsigma .{ }^{1}$ Peter opens this section with 'in the same way', which is likely referring back to the submission of slaves to their masters from the previous section (1 Pt 2:18-25). Therefore, in the same way that slaves have God-given responsibilities with respect to their masters, wives too have their own responsibilities to their husbands (Dubis 2010:83).

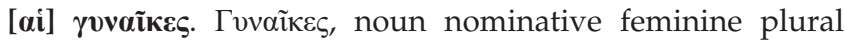
common from $\gamma v v \eta$, could be translated as an adult female person (woman), a married woman (wife) and a newly married woman (bride). However, Peter seems to discuss only about wives: firstly, he uses the example of Sarah in terms of her obedience to Abraham (as husband and wife). Secondly, the use of ióors confines this exhortation to the marriage relationship because it underlines the private and unique relationship by the marriage tie. Although it would be hard to define either those women as brides or wives, the context denotes that those women are wives (3:7). Although the wives are in nominative case, it has a function as vocative (nominative for vocative).

The articular noun more likely serves as a simple substitute for a Semitic noun of address (Metzger 1998-2001:620; Michaels 1988:154), regardless of whether the addressee is inferior or superior (Wallace 1996:68). It is supported by the evidence that the articular for vocative also appears in verse 7 whilst addressing the husbands.

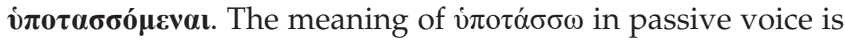
'subject oneself, be subordinated, or obey'. This participle has a function like an imperative (1 Pt 1:14; 2:12, 18; 3:7, 9; 4:8, 10). It means that the use of the participle is not to be attached to any verb in this context, but it is grammatically independent. The middle voice functions as reflexive or direct reflexive (Wallace 1996:416). It means Peter exhorts the woman to act on herself. Therefore, the translation is 'subject yourselves'.

This word appears five times in this book within different contexts (1 Pt 2:13, 18; 3:1, 22; 5:5). Peter always connects the submission of believers to the Lord or Christ. In 1 Peter 2:13, Peter exhorts the believers to subject themselves to human institutions for the Lord's sake, not for the government's sake (1 Pt 2:13), and this is God's will (1 Pt 2:15). In 1 Peter 2:18, he encourages the servants to subject themselves to their masters, not because of their status but to follow Christ's example and to please God (1 Pt 2:20-21). In 1 Peter 5:5, Peter urges the younger to subject to the elders, not because of the status of the elders and that they might oppose them, but because God opposes the proud and gives grace to the humble (1 Pt 5:5). These occurrences provide an idea of submission that is involving recognition of an ordered structure. As this word is also followed by a dative complement of the participle, it points out the appropriate respect should be shown to the ones who have higher status.

1.ónoíws occurs three times in 1 Peter $(3: 1 ; 3: 7 ; 5: 5)$. It has a function to introduce new topic. This word is followed by nominative $(3: 1 ; 3: 7)$ or vocative $(5: 5)$. It denotes
a new subject is inaugurated. This word is not only introducing a new subject but a new subject is inaugurated. This word is not only introducing
also connecting the idea from previous verses to this section.
Interestingly, instead of focusing on their lower status or on the established structure as the reason for their submission (Keener 1993:202); in the marriage context, the wives should thus subject themselves to their own husbands with evangelistic intent having faith in God.

In the LXX (Brenton 2003), besides the meaning of subdued and think carefully, this word is also used as a substitute for

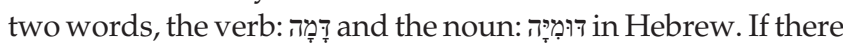
is any relationship in terms of meaning between subjected and stand still, it could be understood that Peter uses this word to encourage the wives. When they subject themselves to their husbands, they might face challenges, especially if their husbands are unbelievers. However, Peter urges them to stand still in their submission with their trust in God (1 Pt 3:5).

iv $\boldsymbol{\alpha}$. This conjunction has a function as a marker to denote the purpose of their submission (Wallace 1996:571). Although the wives might be under undesirable conditions in which to submit, their submission has an evangelistic function (Hiebert 1984:183).

коі. It serves as the intensive adverb and modifies the conditional clause (even if).

\&i. This conjunction could be interpreted in two ways: Firstly,

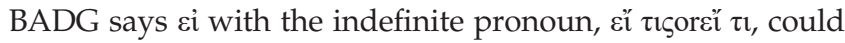
be translated as 'everyone who', 'whoever', 'everything that' or 'whatever' (Mt 16:24; 18:28; Mk 4:23; 9:35; Lk 9:23; 14:26; 1 Ti 3:1, 5; 5:4, 8, 16; 1 Cor 12:31). In favour of this view, Beare elucidates that saying $\varepsilon i$ with the indefinite pronoun is not truly a conditional clause but is more likely an example of the indefinite clause. He gives an example from Philippians 4:8, where si with the indefinite pronoun is not from ő $\sigma o s$ (Beare 1947:127). It is supported by the evidence from 1 Peter itself (4:11): Ei $\tau \iota \varsigma$ appears twice in this verse and it is translated as 'whoever'. As a result, the translation would be, 'those who disobey'. The second view of this conjunction is the first-class condition and indicates 'the assumption of the truth for the sake of argument'. Because this class uses the particle si with the indicative (in any tense) in the protasis (Wallace 1996:690). In my understanding, the first condition view is more plausible. The occurrences of si $\tau \iota \varsigma$ in the New Testament (NT) could be, and most of all are, translated as 'if anyone' (Mt 16:24, Mk 4:23, 8:34, 9:35, Lk 9:23, 14:26; Ac 13:15, Rm 13:9, 1 Cor 3:17, 18, 7:12; 8:2, 10:27, 11:34, 14:37, 16:22; 2 Cor 5:17, 10:7, 11:10; Gl 1:9, Phlp 3:4; 2 Th 3:10; 1 Tm 3:1; 5:16; 6:3; Tt 1:6; Ja 1:23, 26; 3:2, 2 Jn 1:10; Rv 11:5; 13:9, 10; 14:9, 11; 20:15. Exceptions include 1 Cor 7:13, Eph 4:29, Phlp 4:8. Debatable: Phlp 2:1). The exception appears when eí $\tau$ เ serves as an attributive to the main subject (1 Cor 7:13; Eph 4:29), stands as predicate nominative (Phlp 4:8) or a comparative with conjunction $\dot{\omega}$ (1 Pt 4:11). Consequently, the translation would be, 'if those (anyone) who disobey'. This first-class conditional does not mean that, if the wives subject themselves to their husbands, they will certainly win their husbands.

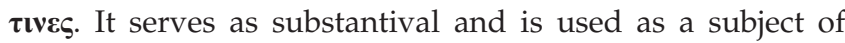

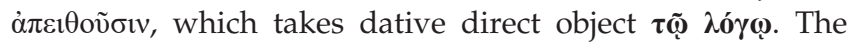


word seems to point to the word of God. It appears four times in 1 Peter and refers to the word of God. The occurrences are one in genitive case (1 Pt 1:23) and two in dative case (1 Pt 2:8; 3:1). With $\dot{\alpha} \pi \varepsilon 10$ oṽ $\sigma v$, this phrase seems to suggest the thought that refusal to believe the gospel is evidence of disobedience to God.

$\boldsymbol{\delta} \mathbf{\imath}$. This preposition is followed by $\tau \tilde{\eta} \varsigma \dot{\alpha} v \alpha \sigma \tau \rho o \varphi \tilde{\eta} \varsigma$. It serves as a marker of instrumentality, whereby something is accomplished or effected. In this case, the behaviour (manner) of their wives serves as an instrument to accomplish evangelistic intent. Behaviour is one of the most important topics in 1 Peter - it appears six times in this letter. Again, Peter insists that his readers must have a Christian conduct an outward life that is formed by Christian faith and love, as this would be the most effective means of overcoming hostility and even of turning opponents into disciples (Beare 1947:128)

ơvev hó $\mathbf{\gamma o v}$. This is an emphasis that winning their husbands and overcoming hostility can be accomplished through their silent testimony of Christian life and character.

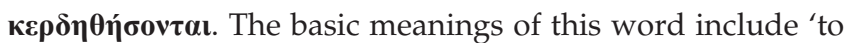
gain' and 'to spare'. Nonetheless, figuratively it has a sense of winning their husbands over to a certain point of view, such as conversion to the Christian faith. The concept of 'winning men to Christ' is also found in 1 Corinthians 9:19-22. It also appears in Matthew 18:15; Philippians 3:8 and 1 Corinthians 2:35.

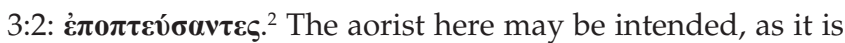
frequently, to indicate time before the main verb

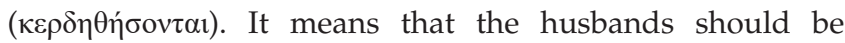
observed before they come to Christ. As this aorist participle identifies the 'observing' as antecedent action, it suits a causal interpretation. Peter reiterates the importance of having a godly life. As their husbands pay close attention to their

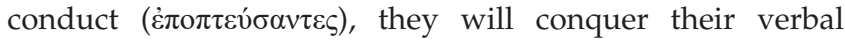
hostility and even win their husbands' souls for Christ by their silent demonstration of its transforming power in their daily conduct. Their society would also struggle to find any wrongdoing. This has the same connotation as in the story of Daniel. The people in Babel sought to find any grounds to raise a complaint against Daniel; however, they could not find any complaint or fault because he was faithful (Dn 6:4). The example from the Old Testament (OT) makes it clear that, by faithfulness and good conduct, the society would be hard-pressed to accuse or slander God's people.

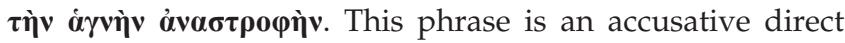

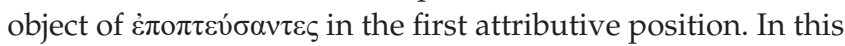
construction, the adjective receives greater emphasis than the substantive (Robertson 1914:776). Hence, the 'holy' receives a

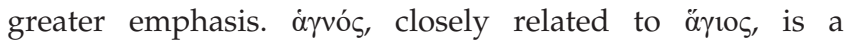
distinctively religious word. It suggests a purity charged with piety and commanding reverence. $\dot{\varepsilon} v$ $\varphi$ ó $\beta \omega$. This is a 2.It appears twice in 1 Peter $(2: 12 ; 3: 2)$. Verb participle aorist active nominative masculine plural from غ̇лолтєú $\omega$.

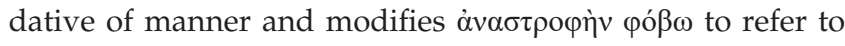
reverence or respect (LXX: Gn 31:42, 53; Ex 20:20; NT: Eph $5: 21$ ). The implicit object of 'fearing' is not the unbelieving husbands but God (Dubis 2010:85). This is made clear in verse 4 , where the focus is on what is precious in God's sight, and in verse 6 by the exhortation not to be overcome by fear (Forbes 2014:84).

\section{Peter 3:3-4: The exhortation to pursue an irresistible beauty}

\section{3:3: Negative way}

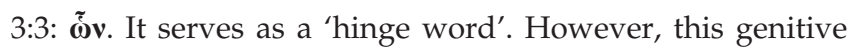
relative pronoun introduces the syntactically difficult verses $3-4$, which hinges on how to interpret $\tilde{\omega} v$ itself. Achtemeier apparently reads this relative pronoun as a predicate of $\tilde{\varepsilon} \sigma \tau \omega$,

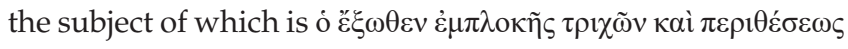

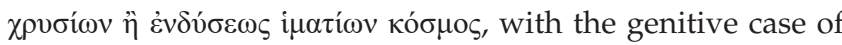
the relative pronoun being possessive (Achtemeier 1996:213; Elliot 2000:561). This would yield the sense '[l]et not external adornment ... be yours, but let the unseen person of the heart ... be yours'. This understanding becomes difficult to carry through in verse 4 . More likely, the predicate is not $\tilde{\omega} v$, but

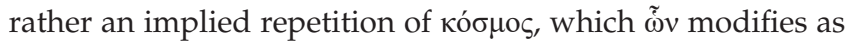
an objective genitive. Verse 4 parallels the same construction,

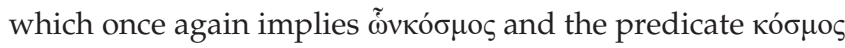
from verse 3. The Greek text of verses 3-4, with implied

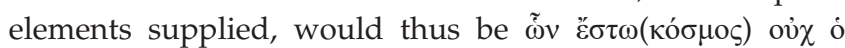

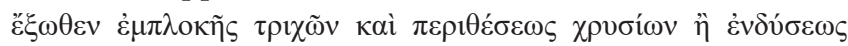

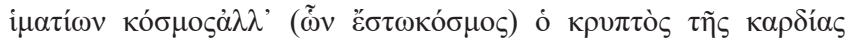

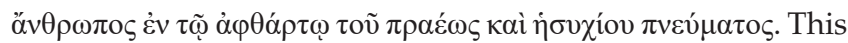
yields the translation (Dubis 2010):

[L]et not the external adornment that consists in hairstyles, jewellery, and clothes be that which beautifies you, but let the unseen person of the heart be that which beautifies you. (p. 86)

More likely, this $\tilde{\tilde{v}} v$ modifies as an objective genitive.

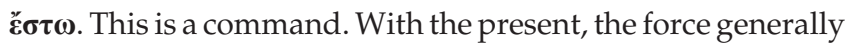
is to command the action as an ongoing process. This is in keeping with the present aspect, which portrays an internal perspective (Wallace 1996:485). Applying this concept, it means that Peter exhorts the wives not to focus on external beauty.

$\boldsymbol{o} \boldsymbol{v} \chi \ldots \dot{\alpha} \lambda \lambda^{\prime}$. Dubis states that this correlative pair functions as a negative-positive construction. It means that this pair serves as a negative clause in verse 3 and a positive clause introduced by $\dot{\alpha} \lambda \lambda$ ' in verse 4 (1 Pt 1:12; Dubis 2010:87).

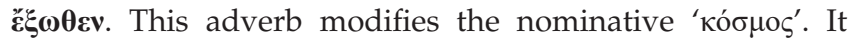
explains the kind of beauty that Peter discusses in this verse. $\check{\varepsilon} \xi \omega \theta \varepsilon v$ is related to a position on a surface or having to do with the outside.

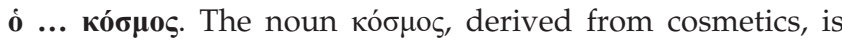
used in its original sense of an orderly arrangement, and 
hence, adornment or decoration (elsewhere in the NT, the term signifies 'the world' as an orderly system). The article goes with кó $\sigma \mu \rho$ s. The reason the article is separated from its subject is because it seems that Peter wants to state specific examples that are parts of larger categories named by кó $\sigma \mu \rho \varsigma$. It is frequently used when the head noun is ambiguous. Consequently, Peter puts the adverb and the three substantial

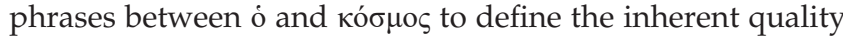
of that adornment.

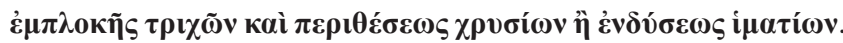
Interestingly enough, all of the words are in noun. Achtemeier (1996:212-213) suggested that the lack of an adjective in the Greek implies that the command regarding hairstyles, jewellery and clothing is not an absolute one but one of emphasis, stressing the importance of inner adornment whilst not completely prohibiting external adornment. In these three genitival phrases, the first genitive in each phrase is likely a subjective genitive because it involves the verbal idea (verbal noun). In support of this, BDAG also translates this first genitive in each phrase as a verbal noun: $\dot{\varepsilon} \mu \pi \lambda \circ \kappa \tilde{\eta} \varsigma: ~ b r a i d i n g ; ~ \pi \varepsilon \rho \imath \theta \dot{\varepsilon} \sigma \varepsilon \omega \varsigma:$ putting on or

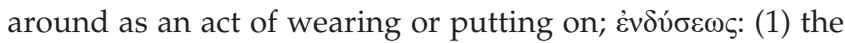
act of putting on, and (2) that which is put on, clothing. Therefore, these first genitives have the function of converting the verbal noun, to which the genitive is related, into a verbal form and turn the genitive into its subject (Wallace 1996:113). The second genitives are objective because, semantically, they serve as the direct object of the verbal idea implicit in the head noun.

$\dot{\varepsilon} \boldsymbol{\mu} \boldsymbol{\pi} \boldsymbol{\lambda} \mathbf{0} \tilde{\boldsymbol{\eta}} \boldsymbol{s}$ is used only here in the NT and denotes an action, so not the use of braids but the elaborate process of braiding that involves the services of a professional hairdresser. In Peter's Day, the hairstyles of fashionable Roman ladies consumed much time and attention, and were highly artificial and ostentatious (Hiebert 1984:186).

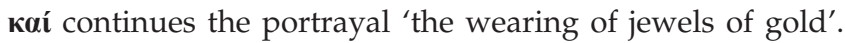
The towering hairdo was secured with costly combs and

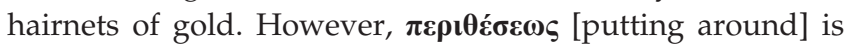
literally broader, as it includes the common practice of placing various golden objects, such as chains, rings and bracelets around the neck, ankles, arms, and fingers, and suspending glittering ornaments from the ears.

The use of $\grave{\eta}$ before the third item implies an alternative method of extravagant display 'or of putting on apparel'.

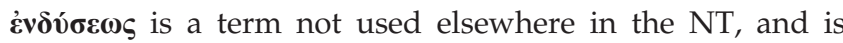
another noun of action which apparently indicates the practice of appearing in a great variety of dresses, 'the frequent changing of frocks' (Wand 1934:90). The Greek term refers particularly to the outer garments worn. Although no direct reference is made to the costly nature of those garments (1 Tm 2:9), the description indicates their sumptuous nature. They were put on for show, that is, for a display of personal vanity. It goes without saying that the design of the passage is not to encourage slovenliness or sordid indifference towards female attire. Nor does it constitute an absolute prohibition of braids or the use of any items of jewellery any more than it forbids the actual putting on of clothes. It is a warning against extravagance and self-centred display. It is possible to be guilty of the evil Peter rebuked by wearing too little, as well as wearing too much (Lillie 1978:188).

\section{3:4: Positive way}

3:4: $\dot{\boldsymbol{\alpha}} \lambda \lambda$ '. Verse 4 commences with a contrastive conjunction. It suggests a contrast or opposing thought to the idea in verse 3. крvлті̀). This word pertains to something that is unknown because of its being hidden. $\kappa \rho v \pi \tau$ ò $\varsigma$ is probably used to contrast with $\tilde{\varepsilon} \xi \omega \theta \varepsilon v$ in the first attributive position.

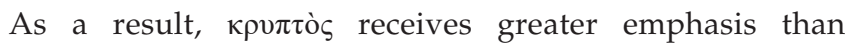
öv $\theta \rho \omega \pi$ os. Interestingly, the real adornment has been described both in verse 3 by the absence of adjective in genitive phrase construction, which places the emphasis not on external adornment, and the article before the adjective in verse 4 , which puts a greater focus on the hidden. In short, the importance of internal adornment is described by two negative conjunctions (ov $\chi$ and $\dot{\alpha} \lambda \lambda^{\prime}$ ), the nouns in the genitive phrase (3:3) and the article before the adjective (3:4).

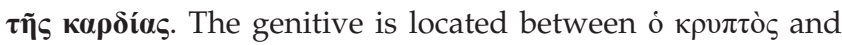
öv $\theta \rho \omega \pi \mathrm{o}$ or in a sandwiched construction. Therefore, $\tau \tilde{\eta} \varsigma$ $\kappa \alpha \rho \delta$ í $\varsigma$ stands as appositional genitive to describe that inner being, the renewed personality, as the seat of life.

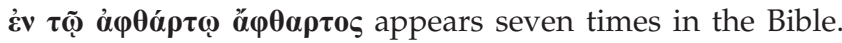
Three occurrences refer to God: the glory of God ( $\operatorname{Rm} 1: 23)$, the word of God (1 Pt 1:23) and God himself (1 Tm 1:17). The other three belong to the eschatological things for believers: a resurrected body (1 Cor 15:52), imperishable wreath (1 Cor 9:25) and future inheritance (1 Pt 1:4). Based on a lexical analysis, it is quite interesting to note that Peter does not apply $\dot{\alpha} \varphi \theta \alpha \dot{\alpha} \rho \tau$ to God or use it in an eschatological sense. However, Peter encourages the wives that they could have imperishable beauty, which does not belong to God or to the future, but which is their godly character in this life. Robertson (1914:758) pointed out that the article could emphasise the quality. Furthermore, $\alpha \varphi \theta \alpha \dot{\alpha} \rho \tau \omega$ is abstract noun by their nature and with the article, it focusses on quality not being subject to corruption. However, the preposition $\dot{\varepsilon} v$ has the function of reinforcing the instrument (Smyth \& Messing 1984:377). The proper translation would be 'with the imperishable quality'.

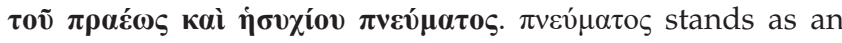
attributed genitive to the $\tau \tilde{\omega} \dot{\alpha} \varphi \theta \dot{\alpha} \rho \tau \varphi$ because $\tau \tilde{\omega} \alpha \dot{\alpha} \varphi \theta \dot{\alpha} \rho \tau \omega$ is functioning (in a sense) as an attributive adjective. The imperishable quality modifies the spirit. The article goes with two adjectives to modify $\pi v \varepsilon v ́ \mu \alpha \tau o s$ by giving two characteristics of it. Therefore, the primary focus is $\pi v \varepsilon v ́ \mu \alpha \tau o \varsigma$.

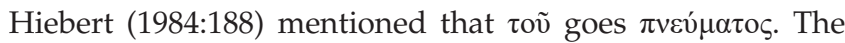


definite article with spirit, 'the spirit', points to the wellknown spirit that characterises the saintly believer's relations

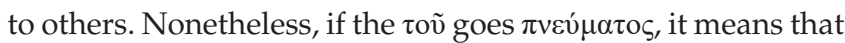
these two adjectives seem to be slightly more emphatic than the noun. This construction, however, is in attributive position. The spirit functions as a subjective genitive of these two genitives as $\pi v \varepsilon v ́ \mu \alpha \tau o \zeta$ functions semantically as the

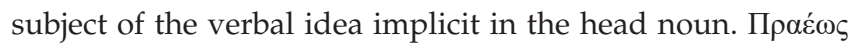
describes her bearing as gentle, considerate and unassuming

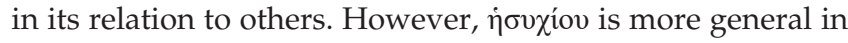
scope. It pictures a quiet disposition as contrasted to a noisy and boisterous attitude. It is a spirit which calmly bears the disturbances created by others and which itself does not create disturbances (Forbes 2014:112).

o. Hiebert (1984:129) mentioned that this relative pronoun could be interpreted in two ways: it could point back to $\pi v \varepsilon v ́ \mu \alpha \tau \sigma \zeta$ as its antecedent or $\dot{\alpha} \varphi \theta \alpha \dot{\alpha} \rho \tau \omega$, or to the entire preceding clause. I believe that it would be better to take it as attaching to the entire preceding clause for several reasons: firstly, contextual argument. Peter exhorts the wives to have true adornment, and he demonstrates it in two ways, both negative and positive, as the whole thought

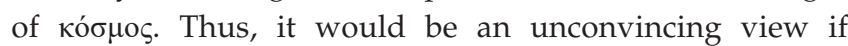
someone takes only one way as something which is precious before God. Secondly, this construction also appears in verse 1 Peter 1:6 and goes back to the whole thought. Therefore, that which is precious in the sight of God is the immortal, imperishable beauty of the inward life, not the richness of outward adornment.

$\pi 0 \lambda v \tau \varepsilon \lambda \varepsilon \dot{s}$. It is pertaining to being a great value or worth. It appears only three times in the NT and one in Septuagint (Is 28:16). In the NT, two of them (Mk 14:3; $1 \mathrm{Tm} 2: 9$ ) refer to outside adornments, such as ointment and garments. However, Peter uses this word ' $\pi 0 \lambda v \tau \varepsilon \lambda \varepsilon^{\varepsilon} \zeta^{\prime}$ to exclusively refer to the inward life. Consequently, Peter encourages them that God himself appraises their inward adornment at high value and as an irresistible beauty.

\section{Peter 3:5: The reason for submission}

3:5: ov๊ $\tau \omega \varsigma$. This adverb has a function to demonstrate in terms of manner, and this form generally refers to what precedes (Smyth \& Messing 1984:307). As a result, Peter points back to the attitude mentioned in previous verses.

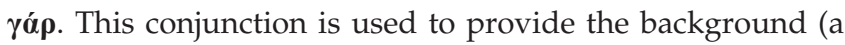
marker of cause) of his exhortation.

$\pi \mathbf{\pi} \tau$. This adverb is pertaining to the time of the past. Peter employs this word to emphasise the wives pursuing inward beauty which is not something new, but it has been performed since the early times by them.

Kó. It is a marker to indicate an additive relation that is not coordinated to connect clauses or sentences and functions as

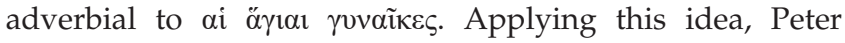
reminds the readers that the saintly wives of the OT themselves did what he is asking them to do.

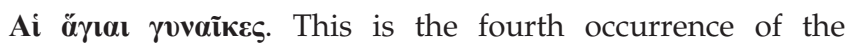
attributive position (one in 3:2 and two in 3:4). Therefore, he focusses his exhortation on these traits using adjective. Peter grounds his exhortation to the holy women. If the wives do what Peter asks, they are in the same category of women as these holy ones. They were holy because they were members of God's people and set apart as belonging to the God of Israel. Enshrined in the OT records, they possessed a personal dignity and spiritual importance for the Christian women whom Peter counselled. As in Hebrews 2, the men and women of Israel's sacred literature are regarded as the heroic predecessors, the famed spiritual ancestry of the house of faith, supplanting in the imagination of the faithful the heroes of Greek and Roman history and legend whom they had been taught to honour and to emulate in the days of their pagan upbringing. Fronmuller (1941:52) mentioned that these exemplary women are identified as the holy women - a specific, unnamed group, 'those women of blessed memory'. Then, Peter refers to OT women to motivate the nascent church to emulate them in the sense of historic continuity with the ancient people of God. Because the Christian women whom Peter addressed placed their hope in God, they and the OT women had a similar perspective. Some of these wives were being treated unfairly by their husbands; however, they were nonetheless instructed to be models of deference through their submission to those husbands (3:1-2).

$\boldsymbol{\alpha} \mathbf{i} \boldsymbol{\varepsilon} \lambda \boldsymbol{\lambda} \boldsymbol{i} \zeta \mathbf{0 v \sigma \alpha \boldsymbol { l }}$. It is an attributive participle form, which

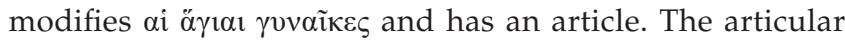
present active participle describes them as a group with the characteristic activity of hoping in God, that is, having a hope that reached up and was resting in God. They lived their daily lives with the expectancy that God would accomplish his promise (Hiebert 1984:189). Furthermore, the participle in the present tense is a habitual (customary) present. It means that holy women regularly place their hope in God in the OT. The present participle could be read as an antecedent or contemporaneous of the main verb

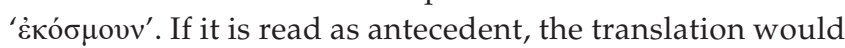
be 'after hoping in God, they used to adorn themselves'. However, if it is present, it would be, 'while hoping in God, they used to adorn themselves'. Nevertheless, it seems that

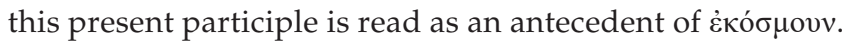
Wallace (1996:622) argued that the participle can be broadly antecedent to the time of the main verb, especially if it is articular. In this case, the participle is articular. Before the OT women adorn themselves, they had their hope in God. In other words, their hope in Christ drives them to adorn themselves in submission. Although hoping in God thus comes before adorning, this hope continues as their habit.

\&iç $\boldsymbol{\theta} \boldsymbol{\varepsilon}$ óv. This phrase occurs four times in 1 Peter - 1:21 (twice), 3:5 and 3:21. Two of them are going with the word hope, in 
either noun or verb, and imply location (putting their hope in God). According to 1 Peter, such a hope should be the true attitude of God's people (1:3; 13, 21; 3:15). Hiebert (1984:189) argued that such a living hope would enable wives to be submissive under difficult and hostile circumstances and would free them from the snare of being preoccupied with excessive adornments.

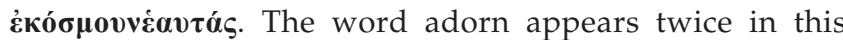
passage. In verse $3: 3$, the adornment appears as a noun. In this verse (3:5), it occurs as a verb. As beauty is the most important topic for women in those days, Peter employs the word beauty not only to get his readers' attention but also to expose an irresistible beauty. The OT women adorned themselves to have an attractive appearance from their submission. Their inward life made them attractive. The imperfect is a customary (habitual) imperfect. Peter views their behaviour to adorn themselves as a regularly recurring activity in past times and as an ongoing state (continually).

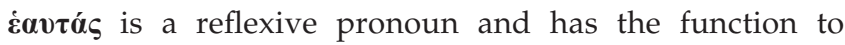
indicate that the subject (holy women) is also the object of adorning. Also, this pronoun is used to highlight the participation of the subject in the verbal action as object (Wallace 1996:350).

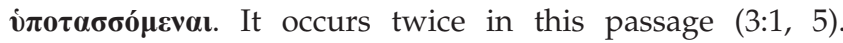
However, this is a manner participle because it indicates the

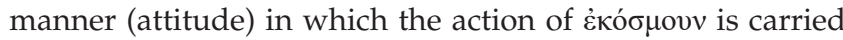
out. Therefore, being in subjection to their own husbands should remind the readers of the time when these holy women used to adorn themselves.

\section{Conclusion}

1 Peter 3:1-5 is an exhortation to all Christian wives to submit to their husbands, whether they are believers, to share the gospel through their submission. Although most women had to submit to their husbands because of their status in marriage as institution, Peter encourages them to submit because it is God's will. Whilst most women adorned themselves outwardly to please their husbands, the apostle emphasises the importance of having the true adornment before God - an inward life of faith and hope. Therefore, Peter's instruction was not only practical but radical as well. As Campbell (1998) asserted:

Undoubtedly, the Christian wives to whom Peter writes have virtually no chance for an egalitarian marital arrangement. Yet for them to remain faithful Christians, maintaining their own religious identity is quite revolutionary. (p. 151)

\section{Acknowledgements Competing interests}

The author declares that he has no financial or personal relationships that may have inappropriately influenced him in writing this article.

\section{Author's contributions}

P.S.C. is the sole author of this article.

\section{Ethical considerations}

This article followed all ethical standards for research without direct contact with human or animal subjects.

\section{Funding information}

This research received no specific grant from any funding agency in the public, commercial, or not-for-profit sectors.

\section{Data availability}

Data sharing is not applicable to this article as no new data were created or analysed in this study.

\section{Disclaimer}

The views and opinions expressed in this article are those of the author and do not necessarily reflect the official policy or position of any affiliated agency of the author.

\section{References}

Achtemeier, P.J., 1996, 1 Peter: A critical \& historical commentary on the Bible, Hermeneia, Augsburg Fortress, Minneapolis, MN.

Beare, F.W., 1947, The first Epistle of Peter, Basil Blackwell, Oxford.

Brenton, L.C.L., 2003, The Septuagint with Apocrypha, 10th edn., Hendrickson Publishers, Peabody, MA.

Brown, J.K., 2004, 'Silent wives, verbal believers: Ethical and hermeneutical considerations in 1 Peter 3:1-6 and its context', Word \& World 24(4), 395-403.

Brown, S., Driver, S.R. \& Briggs, C.A., 1980, A Hebrew and English Lexicon of the Old Testament (BDB), Clarendon Press, Oxford.

Campbell, B.L., 1998, 'Honor, shame and the Rhetoric of 1 Peter', Dissertation Series 160, SBL, Atlanta, GA.

Davids, P.H., 2005, 'A silent witness in marriage: 1 Peter 3:1-7', in R.W. Pierce \& R.M. Groothuis (eds.) Discovering biblical equality: Complementarity without hierarchy, pp. 224-238, InterVarsity Press, Downers Grove, IL.

Dinkler, M.B., 2007, 'Sarah's submission: Peter's Analogy in 1 Peter 3:5-6', Priscilla Papers 21(3), 9-15.

Dubis, M., 2010, 1 Peter, BHGNT, Baylor University Press, Texas, TX.

Elliot, J.H., 2000, 1 Peter, Yale University Press, New Haven, CT.

Ferguson, E., 2003, Backgrounds of early Christianity, William B. Eerdmans Publishing Company, Grand Rapids, MI.

Forbes, G.W., 2014, '1 Peter', in A.J. Köstenberger \& R.W. Yarbrough (eds.), Exegetical guide to the Greek New Testament, B \& H Academic, Nashville, TN.

Frend, W.H.C., 1967, Martyrdom and persecution in the early church: A study of a conflict from the Maccabees to Donatus, University Press, New York, NY.

Fronmuller, G.F.C., 1941, The Epistles General of Peter. Lange's Commentary on the Holy Scriptures, Reprint, transl. J.I. Mombert, Zondervan, Grand Rapids, MI.

Hiebert, D.E., 1984, First Peter, Moody Press, Chicago, IL.

Jobes, K.H., 2005, 1 Peter, BECNT, Baker Publishing Group, Grand Rapids, MI.

Keener, C., 1993, The IVP Bible background commentary: New Testament, InterVarsity Press, Downers Grove, IL.

Lillie, J., 1978, Lectures on the first and second Epistles of Peter, Klock \& Klock, Minneapolis, MN

Metzger, B.M., 1998-2001, A textual commentary on the Greek New Testament American Bible Society, New York, NY

Michaels, J.R., 1988, 1 Peter, Word biblical commentary, vol. 49, Word Books Waco, TX.

Oborn, G.T., 1939, 'Economic factors in the persecutions of the Christians to AD 260', in J.T. McNeill, M. Spinka \& H.R. Willoughby (eds.), Environmental factors in Christian History, pp. 131-148, University of Chicago Press, Chicago, IL.

Robertson, A.T., 1914, A Grammar of the Greek New Testament in the light of historical research, Hodder \& Stoughton, Leicester, London. 
Slaughter, J.R., 1996, 'Instructions to Christian Wives in 1 Peter 3:1-6', Bibliotheca Sacra 153(611), 357-365.

Smyth, H.W. \& Messing, G.M., 1984, Greek grammar, Rev edn. Harvard University Press, Cambridge, MA
Wallace, D.B., 1996, Greek grammar beyond the basics: An exegetical syntax of the New Testament: With scripture, subject, and Greek word indexes, Zondervan, Grand Rapids, ML. Wand, J.W.C., 1934, The General Epistles of St. Peter and St. Jude, Westminster
Commentaries, Methuen, MA. 